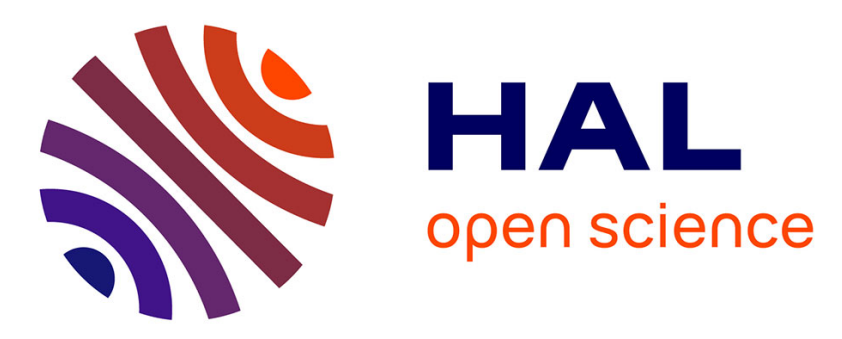

\title{
In vitro differentiation of retinal pigment epithelium from adult retinal stem cells
}

Claudia Aruta, Francesca Giordano, Anna de Marzo, Antonella Comitato, Graça Raposo, Emeline Nandrot, Valeria Marigo

\section{To cite this version:}

Claudia Aruta, Francesca Giordano, Anna de Marzo, Antonella Comitato, Graça Raposo, et al.. In vitro differentiation of retinal pigment epithelium from adult retinal stem cells. Pigment Cell \& melanoma research, 2010, 24 (1), pp.233 - 240. 10.1111/j.1755-148x.2010.00793.x . hal-03086757

\section{HAL Id: hal-03086757 \\ https://hal.science/hal-03086757}

Submitted on 17 Nov 2021

HAL is a multi-disciplinary open access archive for the deposit and dissemination of scientific research documents, whether they are published or not. The documents may come from teaching and research institutions in France or abroad, or from public or private research centers.
L'archive ouverte pluridisciplinaire HAL, est destinée au dépôt et à la diffusion de documents scientifiques de niveau recherche, publiés ou non, émanant des établissements d'enseignement et de recherche français ou étrangers, des laboratoires publics ou privés. 


\title{
In vitro differentiation of retinal pigment epithelium from adult retinal stem cells
}

\author{
Claudia Aruta ${ }^{1}$, Francesca Giordano ${ }^{2,3,4}$, Anna De Marzo ${ }^{1}$, Antonella Comitato ${ }^{1}$, Graça Raposo ${ }^{2,3,4}$, \\ Emeline F. Nandrot ${ }^{5,6,7}$ and Valeria Marigo ${ }^{1}$
}

1 Department of Biomedical Sciences, University of Modena and Reggio Emilia, Modena, Italy 2 Institut Curie, Centre de Recherche, Paris, France $\mathbf{3}$ Structure and Membrane Compartments CNRS, UMR144, Paris, France 4 Cell and Tissue Imaging Facility (IBiSA), Paris, France 5 INSERM, U968, Paris, France 6 UPMC University Paris 06, UMR_S 968, Institut de la Vision, Paris, France 7 CNRS, UMR_7210, Paris, France

CORRESPONDENCE V. Marigo, e-mail: valeria.marigo@unimore.it
KEYWORDS RPE/retinal neurospheres/phagocytosis/EM/melanogenesis

PUBLICATION DATA Received 8 July 2010, revised and accepted for publication 14 October 2010, published online 19 October 2010

doi: 10.1111/j.1755-148X.2010.00793.x

\section{Summary}

One of the limitations in molecular and functional studies of the retinal pigment epithelium (RPE) has been the lack of an in vitro system retaining all the features of in vivo RPE cells. Retinal pigment epithelium cell lines do not show characteristics typical of a functional RPE, such as pigmentation and expression of specific markers. The present study was aimed at the development of culture conditions to differentiate, in vitro, retinal stem cells (RSC), derived from the adult ciliary body, into a functional RPE. Retinal stem cells were purified from murine eyes, grown as pigmented neurospheres and induced to differentiate into RPE on an extracellular matrix substrate using specific culture conditions. After 7-15 days of culture, pigmented cells with an epithelial morphology showed a polarized organization and a capacity for phagocytosis. We detected different stages of melanogenesis in cells at $\mathbf{7}$ days of differentiation, whereas RPE at $\mathbf{1 5}$ days contained only mature melanosomes. These data suggest that our protocol to differentiate RPE in vitro can provide a useful model for molecular and functional studies.

\section{Introduction}

The retinal pigment epithelium (RPE) is highly specialized and polarized. It has important functions in the retina: absorption of stray light, formation of the bloodretinal barrier, regeneration of visual pigments and phagocytosis of outer segments of photoreceptors (Strauss, 2005). Several inherited and degenerative diseases, such as albinism, retinitis pigmentosa and age- related macular degeneration, are associated with impaired RPE functions.

The lack of accurate in vitro models for this tissue hampers functional studies on these diseases. Primary cultures of RPE cells exhibit considerable physiological variability based on donor differences. Alternative sources include cell lines spontaneously created during the passaging of primary cells, such as the human RPE cell lines D407 (Davis et al., 1995) and ARPE-19 (Dunn

\section{Significance}

In vitro development of retinal pigment epithelium (RPE) is of great interest because several retinal inherited and degenerative diseases are associated with RPE defects. Regenerative medicine can be envisioned as a therapeutic approach for these diseases. Furthermore, lack of an in vitro system retaining all the features of in vivo RPE cells has impaired functional and molecular studies on RPE. We describe here a protocol for differentiation into RPE of retinal stem cells derived from adult eyes. We demonstrate gene expression compatible with progressive maturation of RPE. Ultrastructural analysis and functional assays confirm that this differentiation system will provide an in vitro model for RPE studies and melanogenesis. 
et al., 1996), rat RPE cell line BPEl-1 (McLaren et al., 1993) and mouse B6-RPE07 (Chen et al., 2008). Other cell lines have been generated by transformation with the SV40 virus, such as the rat RPE-J cell line (Nabi et al., 1993).

However, all of these cell lines only retain limited characteristics of RPE cells because they lose pigmentation, and show reduced or altered gene expressions, changes in morphology and alteration in metabolic functions (Alge et al., 2003; Campochiaro et al., 1991; Hunt and Davis, 1990; Huotari et al., 1995; Rizzolo, 1990). An innovative and promising method is the use of stem cells that have the ability to differentiate into RPE (Osakada et al., 2008). More interestingly, retinal stem cells (RSC) can be derived from adult murine and human ciliary bodies and cultured in vitro as pigmented neurospheres (RNS) (Coles et al., 2004; Tropepe et al., 2000). These cells have been shown to be able to differentiate in all retinal cell types, including RPE (Tropepe et al., 2000; Vossmerbaeumer et al., 2008). However, in none of the in vitro RPE cultures published so far has a progressive pigmentation, which allows the study of melanosome biogenesis, been reported.

The purpose of this study was to develop culture conditions to differentiate RSC in vitro into a functional RPE to be used as a tool to perform molecular and functional analyses. Melanocytes cannot be considered an appropriate model for RPE melanogenesis because melanocytes and RPE cells have different embryonic origins and show distinctive melanosomal shapes (Smith-Thomas et al., 1996). Furthermore, melanocytes and RPE have different melanogenic gene expression regulation (Bharti et al., 2006, 2008; Murisier et al., 2007). However, little is known about this subject and RPE pigmentation is still not fully understood. The process of melanogenesis in adult RPE is debated because only mature melanosomes can be detected. Although melanosomes are released from melanocytes, the secretion of melanosomes from the RPE has never been reported. Whether this difference is associated to different myosin proteins involved in melanosome transport in the two cell types is still not known. For all of these reasons, we believe that an in vitro model of RPE will be essential for a more detailed characterization of pigmentation and melanogenesis in this tissue.

\section{Results and discussion}

Retinal neurospheres (RNS) were derived from adult mouse ciliary body and cells were cultured at low density $(20$ cells $/ \mu l)$. Retinal neurospheres are clones of pigmented cells derived from the pigmented layer of the ciliary body, as described recently (van der Kooy, personal communication; Takabe et al., 2009, abstract). Cells in RNS share some RPE features such as epithelial morphology and tight junctions, and produce pigment epithelium-derived factor (PEDF) (Moe et al., 2009). We tested different media to induce differentiation of RNS into RPE: Dulbecco's modified Eagle's medium (DMEM)-F12, serum-free medium (SFM), modified Eagle's medium (MEM), DMEM high glucose, and DMEM low glucose with hormone mix (see Methods). Differentiation into RPE was first estimated by morphological analysis. The best protocol for in vitro differentiation of RPE from RNS was as follows: RNS were seeded on extracellular matrix (ECM) and allowed to proliferate for 2 days in SFM with basic fibroblast growth factor (bFGF). At this time, cells migrated out from RNS, lost pigmentation and acquired an elongated shape (Figure $1 A, B$ ). The medium was then changed to DMEM low glucose with hormone mix and the culture continued for 7-15 days. When cells reached confluence they started to pigment again. During this time in culture we did not detect dying cells (data not shown). After 7 days of culture, a monolayer of pigmented cells with epithelial morphology could be seen (Figure 1C).

We previously reported that these same RNS could differentiate, upon specific culture conditions, into neural retina cell types, including rod photoreceptors, bipolar neurons and Müller glia (Giordano et al., 2007). Therefore, we analyzed the characteristics of the RPE-like cells by RT-PCR and immunofluorescence. We found that stem cell and neural progenitor markers $(O c t 3 / 4$, Nanog and Nestin), which are expressed, except for Oct3/4, at higher levels in RNS compared to the ciliary body, were downregulated after 7 days of differentiation (Figure 1D). Moreover, the same cells did not express neural retinal markers such as $P k c \alpha$ (bipolar cell marker) or Rhodopsin (rod marker) (Figure 1E). Pax6, a marker of retinal progenitor cells and, in the adult retina, of amacrine cells, was strongly expressed in RNS and in progenitors after 3 days in culture (Figure $1 F, G$ ), and was downregulated upon RPE differentiation (Figure 1E,H). Similarly, Nestin, a marker of neuronal progenitors, was detectable in RNS and progenitors but not in differentiated RPE (Figure 1I-K).

Different isoforms of the microphthalmia transcription factor (Mitf) are differently expressed in the retina and RPE, and the H-Mitf isoform increases with RPE differentiation (Bharti et al., 2008). Therefore we analyzed A-Mitf, H-Mitf and M-Mitf in our culture isoforms. The three isoforms were all expressed in RNS. A-Mitf and H-Mitf were downregulated in unpigmented progenitors at 3 days of culture (3D), and expression increased again in RPE at 7 and 12 days of differentiation (Figure 1L). Interestingly, the H-Mitf isoform progressively increased during RPE maturation, as found during RPE development (Figure $1 \mathrm{~L}$ and Bharti et al., 2008). M-Mitf isoform is not expressed in RPE and is specific for neural crest-derived melanocytes (Bharti et al., 2008). M-Mitf was detectable only in RNS but not in RPE differentiated in vitro (Figure 1L), confirming differentiation of an RPE-like cell layer and not of pigmented cells with choroidal characteristics. Changes in 
Figure 1. Expression analysis of stem cell and progenitor markers in the in vitro differentiating retinal pigment epithelium (RPE). (A) Pigmented retinal neurosphere (RNS) grown clonally for 7 days. (B) Cells from a RNS, after 2 days on extracellular matrix, gave rise to pigmented and nonpigmented cells with an elongated shape. (C) Retinal pigment epithelium-like cells after 7 days of differentiation formed a monolayer of pigmented cells with a polygonal shape. (D) Real-time PCR analysis of stem cell and progenitor markers (Oct3/4, Nestin, Nanog): relative expression in ciliary body (grey bars) and in RPE-like cells at 8 days of differentiation (black bars) compared to expression in RNS (set as 0) and expressed as log of fold change. (E) Realtime PCR analysis of retinal neuronal markers: Pax6 (retinal progenitors and amacrine cell marker), $P k c \alpha$ (bipolar cell marker) and Rhodopsin (Rho, rod photoreceptor marker) in adult retina (white bars) and RPE-like cells at 8 days of differentiation (black bars). (F-K) Time course of Pax6 $(\mathrm{F}-\mathrm{H})$ and Nestin (I-K) proteins in RNS, RPE-like cells after 3 days of differentiation (RPE 3 days) and RPE-like cells after 15 days of differentiation (RPE 15 days). (L) RT-PCR analysis of $\mathrm{A}-\mathrm{H}$ - and M-Mitf isoforms in RNS, RPE-like cells after 3, 7 and 12 days of differentiation.
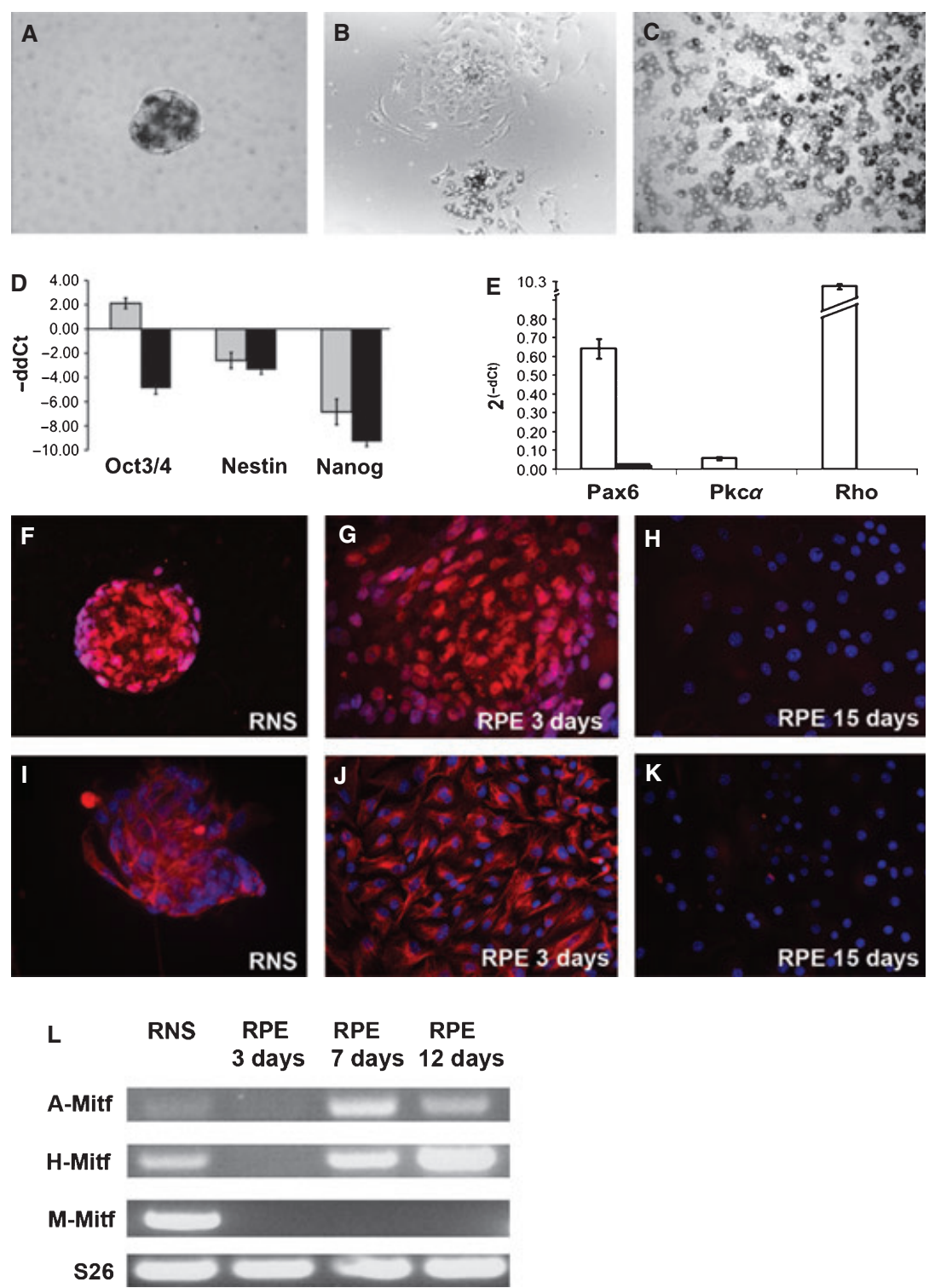

expressions of Pax6 and Mitf in the differentiating RPE culture are consistent with published data showing that Pax6 promotes Mitf expression and, in contrast, that Mitf downregulates Pax6 (Baumer et al., 2003; Tsukiji et al., 2009). These data suggested that cells were activating a specific differentiation program under the tested conditions.

RPE-like cells were further characterized by immunofluorescence. We detected expression of the melanin biosynthesis enzymes tyrosinase-related protein 1 (Tyrp1), dopachrome tautomerase (Dct) and tyrosinase (Figure 2A-C), the pigment cell transcription factor, Mitf (Figure 2D) and the tight-junction epithelial protein ZO-1 (Figure 2E). Expressions of other RPE markers were analyzed at the mRNA level by RT-PCR analysis. We detected expression of other genes that are correlated to different forms of albinism and are important for melanosome biogenesis, such as Pmel17, Matp, Oca2,
Oa1, Mlana and Myo7a (Figure 2K). Mlana, Pme17 and Myo7a were present in RNS, but the other mRNAs were not detectable (Figure 2K). In addition, the pigment epithelium derived factor (Pedf), the retinaldehyde-binding protein (R/bp1) and the gap junction connexin 43 (Cx43) were detected in RNS and at all in vitro differentiation time points of RPE (Figure 2K).

Expression of markers characteristic of mature RPE required a longer differentiation time. In cells differentiated for 15 days we could detect expression of an enzyme involved in the recycling of the photopigment 11-cis-retinal, the RPE-specific 65-kD protein (Rpe65) (Figure 2F). At this same time of differentiation, cells showed a polarized phenotype typical of RPE. We detected the basolateral membrane localization of Bestrophin 1 (Figure 2G), the apical localization of Ezrin (Figure $2 \mathrm{H}$ ) and localization at the apical side and in microvilli of $\beta 5$ integrin and $\mathrm{Na}^{+} / \mathrm{K}^{+}$ATPase (Figure $2 \mathrm{I}-\mathrm{J}$ ). 
Aruta et al.
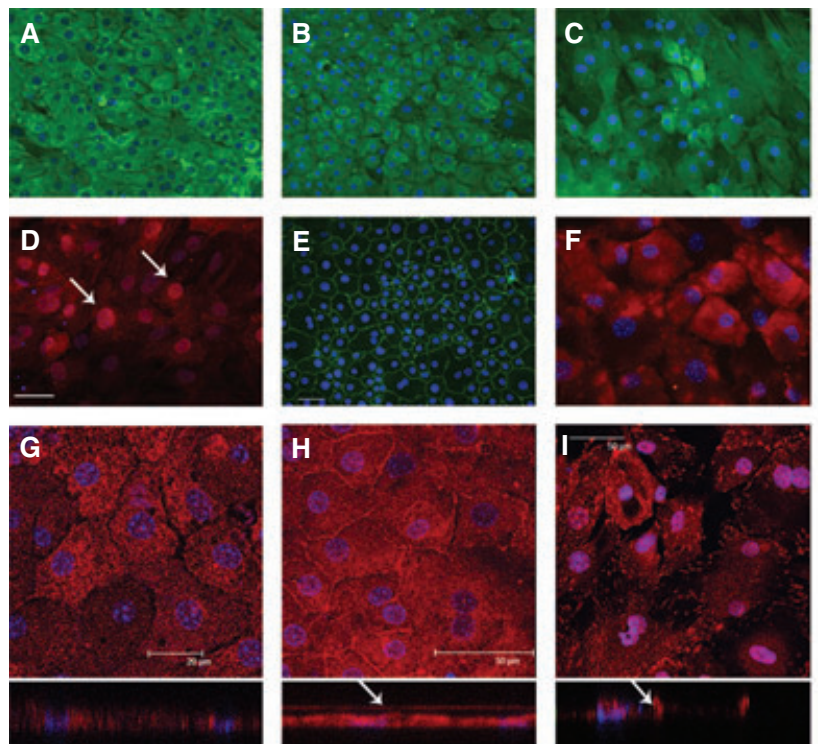
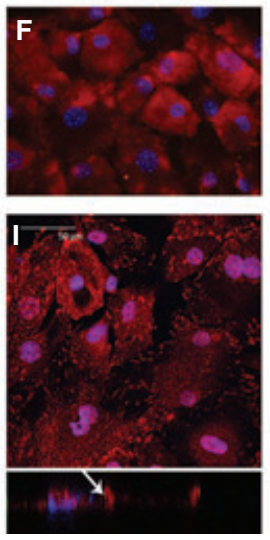
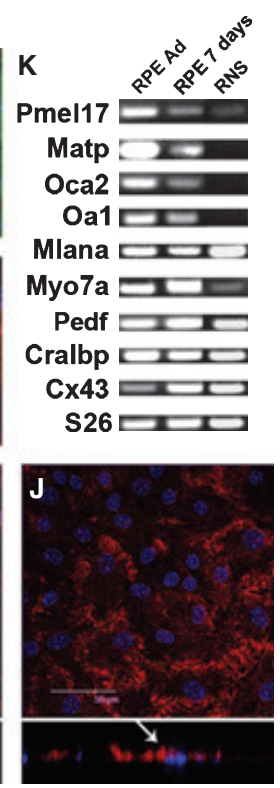

Figure 2. Characterization of retinal pigment epithelium (RPE) markers in RPE-like cells differentiated in vitro. (A-E) Retinal pigment epithelium-like cells after 7 days of differentiation. Expression of enzymes involved in melanin synthesis: Dct in (A), Typr1 in (B), Tyr in (C); pigment cell characteristic transcription factor Mitf in (D) (arrows point to nuclear localization) and epithelial tight-junction protein ZO-1 in (E). (F-J) Retinal pigment epithelium-like cells after 15 days of differentiation. Expression of the RPE-specific enzyme: RPE65 in (F). (G-J) Confocal images of RPE-like cells that form a polarized epithelium: basal localization of Bestrophin 1 (G, lower panel shows the z-axis with Bestrophin localized below and at the level of nuclei in blue); intracellular and apical localization of Ezrin ( $\mathrm{H}$, lower panel shows the z-axis with Ezrin localized above, arrow, and at the level of nuclei in blue); apical localization of $\beta 5$ integrin (I) and $\mathrm{Na}^{+} / \mathrm{K}^{+} \mathrm{ATPase}(\mathrm{J})$ lower panels show the z-axis with $\beta 5$ integrin (l, arrow) and $\mathrm{Na}^{+} / \mathrm{K}^{+}$ATPase ( $\mathrm{J}$, arrow) localized above the nuclei in blue. (K) RT-PCR analysis of RPE genes in adult RPE (RPE Ad), RPE-like cells at 7 days of differentiation (RPE 7 days) and retinal neurospheres. Scale bar: $50 \mu \mathrm{m}$ (D-J); $20 \mu \mathrm{m}$ (G).

We performed electron microscopy (EM) analysis to define the ultrastructural characteristics of in vitro differentiated RPE-like cells and to analyze melanosomes. After 7 days of differentiation melanogenesis was still progressing in some cells (Figure $3 A$ ) and we could identify multivesicular bodies with morphological hallmarks of stage I premelanosomes (Figure 3B), stage I| immature melanosomes, and stage III and stage IV mature melanosomes (Figure 3A, insert). After 15 days of differentiation only stage IV mature melanosomes could be observe (Figure $3 \mathrm{C}$ ). Counts of melanosomes at different stages confirmed that in vitro maturation of RPE-like cells correlated with an increase in stage III and IV melanosomes and a decrease in stage II melanosomes (Figure 3D), similarly to prenatal and postnatal murine RPE (Cortese et al., 2005). Electron microscopy also revealed the presence of microvilli and basement membrane (Figure 3E), adherence junctions (Figure 3F) and caveolae at the plasma membrane (Figure 3G) typical of RPE (Mora et al., 2006).

To confirm that in vitro differentiated RPE was functional, we tested its ability to phagocytose photoreceptor outer segments (POS). Cells, after either 7 or 15 days of differentiation, were exposed to fluoresceinlabeled POS. Because $\beta 5$ integrin and Mer tyrosine kinase (Mertk) mediate binding and internalization of POS, respectively (Feng et al., 2002; Finnemann and
Silverstein, 2001), we investigated co-localization of these molecules with POS. Incubation with POS for $1 \mathrm{~h}$ was sufficient for the binding with $\beta 5$ integrin receptors localized at the apical RPE microvilli (Figure 4A,B). After $3 \mathrm{~h}$ we observed a uniform uptake of POS across the pigmented RPE-like cell monolayer, as revealed by the co-localization of POS and the internalization receptor Mertk (Figure 4C,D). We confirmed that labeled POS were inside the cells by comparing the localization of the lateral tight-junction marker ZO-1 and an apical surface marker $\mathrm{Na}^{+} / \mathrm{K}^{+}$ATPase with POS, using z-axis sections (Figure 4E-H). Fluorescein-labeled POS were observed within the apical region of the cell after $1 \mathrm{~h}$ of incubation (Figure 4B) and inside the cell, proximal to the 4',6-diamidino-2-phenylindole (DAPI) -stained nuclei, after $3 \mathrm{~h}$ of incubation (Figure 4F,H). We observed an increase in internalized POS per cell in RPE-like cells differentiated for 15 days when compared to RPE-like cells differentiated for 7 days (Figure 4l), indicating a direct correlation between POS uptake and in vitro RPE cell maturation.

In this study we provided a differentiation protocol to derive a functional RPE in vitro. By molecular, morphological and functional analyses we showed that pigmented RNS could attach to an ECM substrate, start to proliferate and lose pigmentation. When cells reached confluence, after 7 days of differentiation, we could 
Figure 3. Electron microscopy (EM) analysis. Retinal pigment epithelium (RPE)like cells were analyzed by conventional EM after $7(A-E)$ and 15 days of in vitro differentiation $(C-G)$. (A) Retinal pigment epithelium-like cell differentiated for 7 days harbours melanosomes at different stages of maturation. Insert: high magnification showing presence of immature stage II premelanosomes (II), stage III melanosomes (III) and pigmented mature stage IV melanosomes (IV). Bar: $2 \mu \mathrm{m}$. (B) Example of immature precursors of melanogenesis in an RPE-like cell. Note the presence of multivesicular bodies (MVB) with hallmarks of stage I premelanosomes, multilamellar bodies (MLB) and pigmented multilamellar bodies (asterisks). (C) Retinal pigment epitheliumlike cells differentiated for 15 days contain stage IV mature melanosomes. Bar: $500 \mathrm{~nm}(\mathrm{~B}, \mathrm{C})$. (D) Histogram representing the number of immature (stage II) and mature (stage III, IV) melanosomes per area $\left(160 \mu \mathrm{m}^{2}\right)$ in RPE cells differentiated for 7 ( 7 days) or 15 days ( 15 days). (E) Retinal pigment epithelium-like cells show apical villi (arrows) and basement membrane (bm). (F) Example of zonula adherens (arrow). Melanosomes can be found in cells showing microvilli. (G) Example of caveolae at the plasma membrane (arrows). Bars: $500 \mathrm{~nm}(\mathrm{E}-\mathrm{G})$. $\mathrm{n}$, nucleus; $\mathrm{m}$, mitochondria.
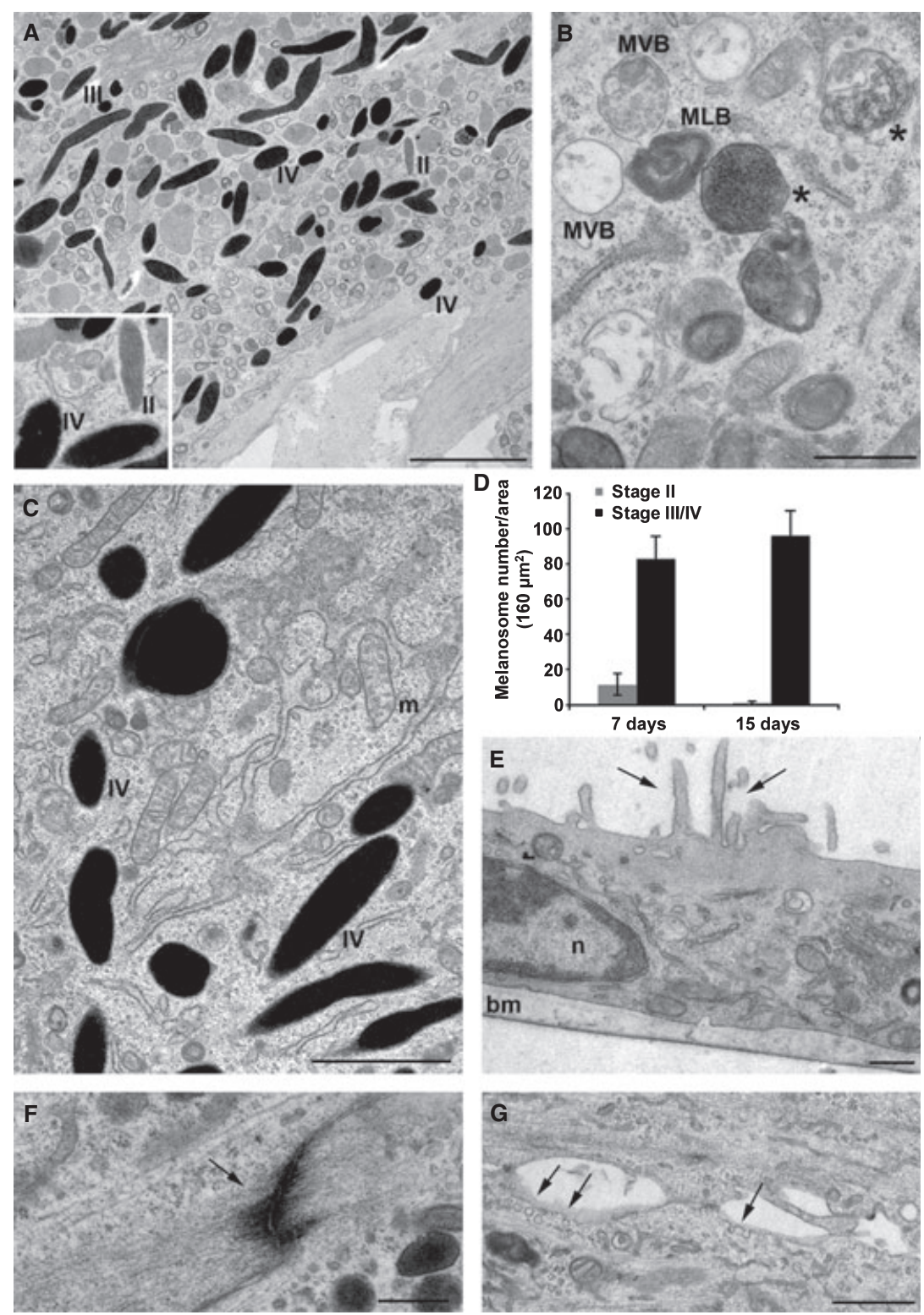

detect melanogenesis; and functionality was observed after 15 days in vitro. Our data suggest that RPE derived from RNS can differentiate in vitro, activating melanogenesis, and therefore can provide an accurate in vitro model for pigmentation studies of RPE that have not been possible so far.

\section{Methods}

\section{RPE generation from adult retinal stem cell}

All procedures on mice (including their euthanasia) were performed in accordance with the ARVO Statement for the Use of Animals in Ophthalmic and Vision Research and with institutional guidelines for animal research. We used C57BL/6 and CD-1 mice, purchased from Charles River Italy (Calco, Italy) and housed under standard conditions with a 12-h light/dark cycle. We dissected eyes and isolated RSC as previously described (Giordano et al., 2007). Retinal neurospheres were picked after 7 days of culture and placed on glass coverslips coated with ECM (Sigma, Milan, Italy) in a serumfree medium (DMEM-F12 with $0.6 \%$ glucose, N2 hormone mix, $20 \mathrm{ng} / \mathrm{ml} \mathrm{bFGF;} \mathrm{Invitrogen,} \mathrm{Milan,} \mathrm{Italy).} \mathrm{Two} \mathrm{days} \mathrm{later,} \mathrm{the}$ medium was replaced with differentiating medium (DMEM low glucose with $1 \%$ fetal calf serum (FCS), $2 \mathrm{mM} \mathrm{L-glutamine,} 100 \mathrm{U} / \mathrm{ml}$ penicillin, $100 \mu \mathrm{g} / \mathrm{ml}$ streptomycin and hormone mix: $1.4 \times 10^{-8} \mathrm{M}$ selenious acid, $2.8 \times 10^{-8} \mathrm{M}$ hydrocortisone, $3 \times 10^{-7} \mathrm{M}$ linoleic acid, $8.3 \times 10^{-7} \mathrm{M}$ insulin, $6.3 \times 10^{-8} \mathrm{M}$ transferrin, $2.4 \times 10^{-6} \mathrm{M}$ putrescine, $10^{-11} \mathrm{M}$ triiodothyronine). Cell culture was extended for 7-15 days. Cell death was assessed by staining for $1 \mathrm{~min}$ with $2 \mu \mathrm{M}$ of the cell impermeable dye Ethidium Homodimer 2 (Invitrogen).

\section{Immunofluorescence}

Immunofluorescence experiments were performed as previously reported (Giordano et al., 2007). The following primary antibodies 

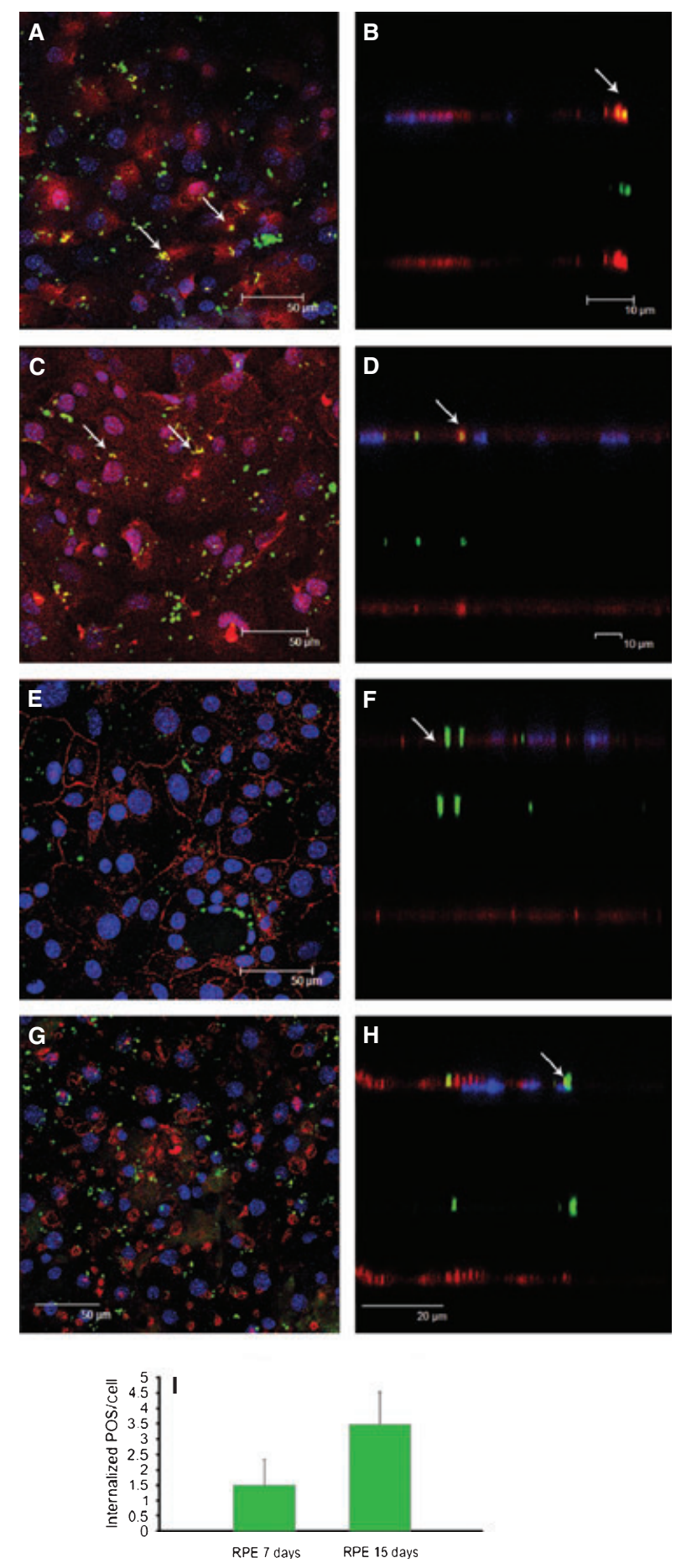

were used: anti-Tyr PEP7, anti-Tyrp1 PEP1 and anti-Dct PEP8 (1:300 from Dr Hearing); anti ZO-1 (1:100; Invitrogen); anti- $\beta 5$ Integrin (1:20; Abcam, Cambridge, UK); anti $\mathrm{Na}^{+} / \mathrm{K}^{+}$ATPase (1:100; Santa Cruz Biotechnology, Heidelberg, Germany); anti-Bestrophin (1:1000; Novus Biologicals, Cambridge, UK); anti-Mertk (1:50; R\&D Systems, Minneapolis, MN, USA); anti-Ezrin (1:250; Sigma); anti-Rpe65 (1:200 from Dr Redmond); anti-Pax6 (1:10 from Dr van Heyningen); anti-Nestin (1:400; Chemicon, Vimodrone, Italy). Secondary antibodies were used as follows: 1:1000 Oregon Green ${ }^{\circledR}$ 488 goat anti-mouse (Invitrogen), 1:1000 Alexa Fluor ${ }^{\circledR} 568$ goat
Figure 4. Phagocytosis assay. Retinal pigment epithelium (RPE)like cells were exposed to fluorescein-labeled photoreceptor outer segments (POS). Confocal images were taken after immunofluorescence with RPE markers. (A) RPE-like cells bind POS (green) through $\beta 5$ integrin (red) after $1 \mathrm{~h}$ of incubation. (B) z-axis showing merged image of co-localization of POS with $\beta 5$ integrin (arrow) at the top; fluorescein-labeled POS in the middle; $\beta 5$ integrin in red at the bottom; (C) RPE-like cells bind POS (green) through Mertk (red) after $3 \mathrm{~h}$ of incubation. (D) z-axis showing merged image of co-localization of POS with Mertk (arrow) at the top; fluorescein-labeled POS in the middle; Mertk in red at the bottom. (E) POS internalization is confirmed by immunostaining of ZO-1 (red). (F) z-axis showing no co-localization of POS with ZO-1 localized at the tight junctions (merged image at the top); fluorescein-labeled POS in the middle; ZO-1 in red at the bottom. (G) POS internalization is confirmed by immunostaining of $\mathrm{Na}^{+} / \mathrm{K}^{+}$ATPase (red). (H) z-axis showing no co-localization of POS with $\mathrm{Na}^{+} / \mathrm{K}^{+}$ATPase localized at the apical membrane (merged image at the top); fluorescein-labeled POS in the middle; $\mathrm{Na}^{+} / \mathrm{K}^{+}$ATPase in red at the bottom. (I) Quantification of internalized POS/cell: phagocytosis significantly increases $(P \leq 0.01)$ with RPE differentiation from 7 to 15 days in vitro.

anti-rabbit (Invitrogen) and 1:200 Cy ${ }^{\text {TM} 3-c o n j u g a t e d ~ m o u s e ~ a n t i-g o a t ~}$ (Jackson ImmunoResearch, Suffolk, UK). Coverslips were mounted with mowiol 4-88 (Sigma) and analyzed in an Axioskop 40 fluorescence microscope (Zeiss, Arese, Italy) and with a Leica laser confocal microscope system.

\section{RT-PCR and real-time PCR}

Total RNA was extracted from adult RPE, RNS and in vitro differentiated RPE using RNeasy Mini Kit (Qiagen, Milan, Italy) according to the manufacturer's instructions. cDNA was synthesized using Transcriptor High Fidelity cDNA Synthesis Kit (Roche, Milan, Italy). Realtime PCR was carried out with the ABI PRISM 7900 HT Sequence Detection System (Applied Biosystems, Monza, Italy) as previously described (Giordano et al., 2007) and normalized using the ribosomal gene S26. The primers used for quantitative PCR are listed in Table 1. Primers used for the identification of Mitf isoforms were as in Bharti et al. (2008).

\section{Electron microscopy}

In vitro differentiated RPE cells grown on coverslips were fixed with $2.5 \%$ glutaraldehyde in $0.1 \mathrm{M}$ cacodylate buffer $(\mathrm{pH}$ 7.4) for $24 \mathrm{~h}$ and then processed according to the procedure described in Giordano et al. (2009). Melanosomes were counted as described in Giordano et al. (2009).

\section{Binding and phagocytosis of POS}

Porcine POS were isolated and fluorescein-labeled as described in Nandrot et al. (2008). RPE cells differentiated in vitro for either 7 or 15 days were incubated with $1 \times 10^{7} \mathrm{POS} / \mathrm{ml}$ for 1 and $3 \mathrm{~h}$ to allow binding and internalization, respectively. Cells were then quenched with trypan blue solution, washed three times in phosphate-buffered saline (PBS) and fixed with $4 \%$ paraformaldehyde for $10 \mathrm{~min}$. Cells were then processed for immunofluorescence and analyzed with a Leica laser confocal microscope system. Quantitative analysis of internalized POS was performed by counting fluorescein-labeled POS in 10 fields per experiment after quenching non-internalized POS with trypan blue. The number of cells in the field was evaluated by nuclear counting. Mean values were reported as POS numbers per cell and P-values were determined by Student's t-test. 
Table 1. Sequences of primers ( $F$, forward; $R$, reverse) used for real-time PCR and RT-PCR experiments. We report the official name of the genes and the commonly used names in parentheses

\begin{tabular}{|c|c|}
\hline Gene & Primer sequence $\left(5^{\prime}-3^{\prime}\right)$ \\
\hline \multirow[t]{2}{*}{ Gja1 (Cx43) } & F: CTTTGGCGTGCCGGCTTC \\
\hline & R: ACCCCAAGCTGACTCAACC \\
\hline \multirow[t]{2}{*}{ Gpr143 (Oa1) } & F: CCTGGGAATCGTTATCAGGT \\
\hline & R: GTACTGGCATCTGAATCTTC \\
\hline \multirow[t]{2}{*}{ Mlana (Mart1) } & F: GACGAAGTGGATACAGAACC \\
\hline & R: CTCTTGAGAAGACAGTCGGC \\
\hline \multirow[t]{2}{*}{ Myo7a } & F: CGCTACCGGGACCACCTC \\
\hline & R: GGGCATCTCCСCTATCTTC \\
\hline \multirow[t]{2}{*}{ Nanog } & F: GGCAGAAAAACCAGTGGTTGA \\
\hline & R: CTGCAATGGATGCTGGGATAC \\
\hline \multirow[t]{2}{*}{ Nestin } & F: AGCTGGCTGTGGAAGCCC \\
\hline & R: CTCTGTAGACCCTGCTTCTC \\
\hline \multirow[t]{2}{*}{ Oca2 } & F: СTCTGCTCTGGAATTCATCC \\
\hline & R: ATGCATTTTTGCTCCCAGGC \\
\hline \multirow[t]{2}{*}{ Pax6 } & F: GCGGAAGCTGCAAAGAAATA \\
\hline & R: TGGCCTGTCTTCTCTGGTTC \\
\hline \multirow[t]{2}{*}{$\mathrm{Pkc} \alpha$} & F: TGCCTTCTTCTTCAGGAGAATCGA \\
\hline & R: TTTCTGCTCCTTTGCCACACA \\
\hline \multirow[t]{2}{*}{ Pou5f1 (Oct3/4) } & F: CTGTTCCCGTCACTGCTCTG \\
\hline & R: TGGTGCCTCAGTTTGAATGC \\
\hline \multirow[t]{2}{*}{ Rhodopsin (Rho) } & F: AATCTCGAGGGCTTTCTTTGC \\
\hline & R: CCACGTAGCGCTCAATGGC \\
\hline \multirow[t]{2}{*}{ Rlbp1 } & F: TCTTGAAGAACAAGCTGCTAC \\
\hline & R: CTGTGTTCTCAACTTCAGCC \\
\hline \multirow[t]{2}{*}{ Slc45a2 (Matp) } & F: AAGTTTGTCATTCGGAACATT \\
\hline & R: GATCGATTCCTAACAACCTTG \\
\hline \multirow[t]{2}{*}{ S26 } & F: GCTGTGCTGACTGTCCCC \\
\hline & R: CGGGTGATTCAAACAACGAC \\
\hline \multirow[t]{2}{*}{ Serpinf1 (Pedf) } & F: TCATTAATGATGGGCCTACAC \\
\hline & R: CATCAGGCTCCTGTGGATAC \\
\hline \multirow[t]{2}{*}{ Si (Pmel17) } & F: ССТССАСТАССАТGСССТССТ \\
\hline & R: CCCAGTCTATGGCACCCAAA \\
\hline
\end{tabular}

\section{Acknowledgements}

We are grateful to Dr Hearing, Dr van Heyningen and Dr Redmond for antibodies. We acknowledge the CIGS of the University of Modena for providing confocal microscopy assistance. V.M. was supported by research grants GGP06096 from Fondazione Telethon, 1R01EY015136-01 and Progetti di ricerca a carattere internazionale from Fondazione Cassa di Risparmio di Modena. E.F.N. was supported by Fondation Voir et Entendre and Fondation Bettencourt Schueller (Young Investigator Grants), Centre National de la Recherche Scientifique (CNRS); the Institut de la Vision is funded by Institut National de la Santé et de la Recherche Médicale, Université Pierre et Marie Curie-Paris 6, Centre National de la Recherche Scientifique, Départment de Paris and Région Ile-de-France.

\section{References}

Alge, C.S., Suppmann, S., Priglinger, S.G., Neubauer, A.S., May, C.A., Hauck, S., Welge-Lussen, U., Ueffing, M., and Kampik, A. (2003). Comparative proteome analysis of native differentiated and cultured dedifferentiated human RPE cells. Invest. Ophthalmol. Vis. Sci. 44, 3629-3641.

Baumer, N., Marquardt, T., Stoykova, A., Spieler, D., Treichel, D., Ashery-Padan, R., and Gruss, P. (2003). Retinal pigmented epithelium determination requires the redundant activities of Pax and Pax6. Development 130, 2903-2915.

Bharti, K., Nguyen, M.T., Skuntz, S., Bertuzzi, S., and Arnheiter, H. (2006). The other pigment cell: specification and development of the pigmented epithelium of the vertebrate eye. Pigment Cell Res. 19, 380-394.

Bharti, K., Liu, W., Csermely, T., Bertuzzi, S., and Arnheiter, H. (2008). Alternative promoter use in eye development: the complex role and regulation of the transcription factor MITF. Development 135, 1169-1178.

Campochiaro, P.A., Hackett, S.F., and Conway, B.P. (1991). Retinoic acid promotes density-dependent growth arrest in human retinal pigment epithelial cells. Invest. Ophthalmol. Vis. Sci. 32, 65-72.

Chen, M., Muckersie, E., Robertson, M., Fraczek, M., Forrester, J.V., and Xu, H. (2008). Characterization of a spontaneous mouse retinal pigment epithelial cell line B6-RPE07. Invest. Ophthalmol. Vis. Sci. 49, 3699-3706.

Coles, B.L., Angenieux, B., Inoue, T., Del Rio-Tsonis, K., Spence, J.R., Mcinnes, R.R., Arsenijevic, Y., and Van Der Kooy, D. (2004). Facile isolation and the characterization of human retinal stem cells. Proc. Natl Acad. Sci. U S A 101, 15772-15777.

Cortese, K., Giordano, F., Surace, E.M., Venturi, C., Ballabio, A., Tacchetti, C., and Marigo, V. (2005). The ocular albinism type 1 (OA1) gene controls melanosome maturation and size. Invest. Ophthalmol. Vis. Sci. 46, 4358-4364.

Davis, A.A., Bernstein, P.S., Bok, D., Turner, J., Nachtigal, M., and Hunt, R.C. (1995). A human retinal pigment epithelial cell line that retains epithelial characteristics after prolonged culture. Invest. Ophthalmol. Vis. Sci. 36, 955-964.

Dunn, K.C., Aotaki-Keen, A.E., Putkey, F.R., and Hjelmeland, L.M. (1996). ARPE-19, a human retinal pigment epithelial cell line with differentiated properties. Exp. Eye Res. 62, 155-169.

Feng, W., Yasumura, D., Matthes, M.T., Lavail, M.M., and Vollrath, D. (2002). Mertk triggers uptake of photoreceptor outer segments during phagocytosis by cultured retinal pigment epithelial cells. J. Biol. Chem. 277, 17016-17022.

Finnemann, S.C., and Silverstein, R.L. (2001). Differential roles of CD36 and alphavbeta5 integrin in photoreceptor phagocytosis by the retinal pigment epithelium. J. Exp. Med. 194, 12891298.

Giordano, F., De Marzo, A., Vetrini, F., and Marigo, V. (2007). Fibroblast growth factor and epidermal growth factor differently affect differentiation of murine retinal stem cells in vitro. Mol. Vis. 13, 1842-1850.

Giordano, F., Bonetti, C., Surace, E.M., Marigo, V., and Raposo, G. (2009). The ocular albinism type 1 (OA1) G-protein-coupled receptor functions with MART-1 at early stages of melanogenesis to control melanosome identity and composition. Hum. Mol. Genet. $18,4530-4545$.

Hunt, R.C., and Davis, A.A. (1990). Altered expression of keratin and vimentin in human retinal pigment epithelial cells in vivo and in vitro. J. Cell. Physiol. 145, 187-199.

Huotari, V., Sormunen, R., Lehto, V.P., and Eskelinen, S. (1995). The polarity of the membrane skeleton in retinal pigment epithelial cells of developing chicken embryos and in primary culture. Differentiation 58, 205-215.

McLaren, M.J., Sasabe, T., Li, C.Y., Brown, M.E., and Inana, G. (1993). Spontaneously arising immortal cell line of rat retinal pigmented epithelial cells. Exp. Cell Res. 204, 311-320.

Moe, M.C., Kolberg, R.S., Sandberg, C., Vik-Mo, E., Olstorn, H., Varghese, M., Langmoen, I.A., and Nicolaissen, B. (2009). A comparison of epithelial and neural properties in progenitor cells derived from the adult human ciliary body and brain. Exp. Eye Res. 88, 30-38. 


\section{Aruta et al.}

Mora, R.C., Bonilha, V.L., Shin, B.C., Hu, J., Cohen-Gould, L., Bok, D., and Rodriguez-Boulan, E. (2006). Bipolar assembly of caveolae in retinal pigment epithelium. Am. J. Physiol. Cell Physiol. 290, C832-C843.

Murisier, F., Guichard, S., and Beermann, F. (2007). Distinct distal regulatory elements control tyrosinase expression in melanocytes and the retinal pigment epithelium. Dev. Biol. 303, 838847.

Nabi, I.R., Mathews, A.P., Cohen-Gould, L., Gundersen, D., and Rodriguez-Boulan, E. (1993). Immortalization of polarized rat retinal pigment epithelium. J. Cell Sci. 104 (Pt 1), 37-49.

Nandrot, E.F., Chang, Y., and Finnemann, S.C. (2008). Alphavbeta5 integrin receptors at the apical surface of the RPE: one receptor, two functions. Adv. Exp. Med. Biol. 613, 369-375.

Osakada, F., Ikeda, H., Mandai, M., Wataya, T., Watanabe, K., Yoshimura, N., Akaike, A., Sasai, Y., and Takahashi, M. (2008). Toward the generation of rod and cone photoreceptors from mouse, monkey and human embryonic stem cells. Nat. Biotechnol. 26, 215-224.

Rizzolo, L.J. (1990). The distribution of $\mathrm{Na}^{+}, \mathrm{K}^{+}$-ATPase in the retinal pigmented epithelium from chicken embryo is polarized in vivo but not in primary cell culture. Exp. Eye Res. 51, 435-446.
Smith-Thomas, L., Richardson, P., Thody, A.J., Graham, A., Palmer, I., Flemming, L., Parsons, M.A., Rennie, I.G., and Macneil, S. (1996). Human ocular melanocytes and retinal pigment epithelial cells differ in their melanogenic properties in vivo and in vitro. Curr. Eye Res. 15, 1079-1091.

Strauss, O. (2005). The retinal pigment epithelium in visual function. Physiol. Rev. 85, 845-881.

Takabe, B.L.K., Clarke, L., and van der Kooy, D. (2009). Purification of mouse retinal stem cells. ISSCR 7th Annual Meeting, Abstract 1610.

Tropepe, V., Coles, B.L., Chiasson, B.J., Horsford, D.J., Elia, A.J., Mcinnes, R.R., and Van Der Kooy, D. (2000). Retinal stem cells in the adult mammalian eye. Science 287, 2032-2036.

Tsukiji, N., Nishihara, D., Yajima, I., Takeda, K., Shibahara, S., and Yamamoto, H. (2009). Mitf functions as an in ovo regulator for cell differentiation and proliferation during development of the chick RPE. Dev. Biol. 326, 335-346.

Vossmerbaeumer, U., Kuehl, S., Kern, S., Kluter, H., Jonas, J.B., and Bieback, K. (2008). Induction of retinal pigment epithelium properties in ciliary margin progenitor cells. Clin. Exp. Ophthalmol. 36, 358-366. 